\title{
The Diverse Applications of Recombinant BCG-Based Vaccines to Target Infectious Diseases Other Than Tuberculosis: An Overview
}

\author{
Esma Mouhoub ${ }^{1,2,3}$, Pilar Domenech ${ }^{2,3}$, Momar Ndao ${ }^{1,2,3,4,5 *}$ and Michael B. Reed ${ }^{1,2,3,4 *}$ \\ ${ }^{1}$ Department of Microbiology \& Immunology, McGill University, Montreal, QC, Canada, ${ }^{2}$ Infectious Diseases and Immunity in \\ Global Health Program, Research Institute of the McGill University Health Centre, Montreal, QC, Canada, ${ }^{3}$ McGill \\ International TB Centre, McGill University, Montreal, QC, Canada, ${ }^{4}$ Department of Medicine, McGill University, Montreal, QC, \\ Canada, ${ }^{5}$ National Reference Centre for Parasitology, Research Institute of the McGill University Health Centre, Montreal, \\ QC, Canada
}

\section{OPEN ACCESS}

Edited by:

Axel Cloeckaert,

Institut National de recherche pour l'agriculture, l'alimentation et l'environnement (INRAE), France

Reviewed by:

Sunil Joshi,

University of Miami, United States

Arshad Khan,

University of Texas Health Science Center at Houston, United States

*Correspondence: Momar Ndao momar.ndao@mcgill.ca Michael B. Reed michael.reed@mcgill.ca

Specialty section:

This article was submitted to Infectious Agents and Disease, a section of the journal

Frontiers in Microbiology

Received: 12 August 2021 Accepted: 30 September 2021 Published: 21 October 2021

Citation:

Mouhoub E, Domenech P, Ndao M and Reed MB (2021) The Diverse Applications of Recombinant BCG-Based Vaccines to Target Infectious Diseases Other Than

Tuberculosis: An Overview.

Front. Microbiol. 12:757858. doi: 10.3389/fmicb.2021.757858
Live attenuated Bacillus Calmette-Guérin (BCG) is the world's most widely used vaccine which is mainly administered for its protection against tuberculosis (TB), particularly in young children. However, since its initial use over 100 years ago, it has also proven to offer a level of protection against various other pathogens, as a consequence of its non-specific immune enhancing effects. Thus, over the past few decades, recombinant $B C G$ ( $r B C G$ ) technology has been used as a vector to create rBCG vaccines expressing heterologous antigens that elicit immunity against a range of bacterial, viral, and parasitic diseases. Our goal with this mini-review is to provide an up-to-date survey of the various techniques, approaches, and applications of rBCG-based vaccines for targeting infectious diseases other than TB.

Keywords: Bacillus Calmette-Guérin, recombinant BCG, infectious diseases, vaccine development, bacterial vector

\section{INTRODUCTION}

BCG is an attenuated form of the Mycobacterium bovis (M. bovis) bacteria, a close relative of Mycobacterium tuberculosis (M. tb), and is currently used to vaccinate infants against TB meningitis and miliary disease (Mahairas et al., 1996; Zimmermann et al., 2019). According to the recently updated BCG Atlas, BCG is the most universally given vaccine across the globe with over 160 million infants receiving the vaccine annually (Zimmermann et al., 2019), although long-term efficacy may vary globally (Angelidou et al., 2020). The benefits of BCG vaccination include its heat stability, easy mass production, low cost, and safe neonatal use, it is unaffected by maternal antibodies, and it is associated with induction of non-specific heterologous immunomodulatory effects (Kilpeläinen et al., 2019; Zimmermann et al., 2019). Indeed, BCG immunization at birth induces cross-protection for a number of infectious pathogens including M. tb, Candida albicans, Staphylococcus aureus, respiratory syncytial virus (RSV), influenza A virus, and herpes simplex virus type 2, due to its non-specific immunomodulatory, or adjuvant-like, effects (Starr et al., 1976; Spencer and Ganguly, 1977; Van't Wout et al., 1992; Kleinnijenhuis et al., 2012; Nemes et al., 2018; Covián et al., 2019; 
O'Neill and Netea, 2020). While an in-depth discussion of the various immune-related mechanisms associated with BCG is beyond the scope of the present article, in recent years, it has been demonstrated that BCG is able to trigger the epigenetic reprogramming of innate immune cells ("trained immunity") that may function as APC (antigen-presenting cells), as well as augmenting T-cell immunity by stimulating IFN- $\gamma$ production and subsequent Th1 cellular responses (Kleinnijenhuis et al., 2012, 2015; Zimmermann et al., 2019).

The BCG bacterium now exists globally as a range of genetically distinct substrains that lack varying genomic regions relative to $M$. $t b$ and $M$. bovis. The common deletion of RD1 (Region of Difference 1) that is present in all BCG strains is a major cause of attenuation (Conrad et al., 2017; Tiwari et al., 2019). The latter encodes a vital part of the type VII secretion system of $M$. tb, known as ESX-1 (Majlessi et al., 2005). Although BCG diversification has led to heterogeneous substrains, to date, no significant difference in efficacy has been reported in humans among the various substrains (Milstien and Gibson, 1990; Behr and Small, 1999). In animal studies, the immunogenicity of BCG appears to vary in a strain, dose, and delivery-dependent manner. In addition, comparative analyses in mice have reported differences in efficacy and virulence across 13 diverse BCG substrains (Zhang et al., 2016). Low doses of BCG elicit an almost exclusively Th1 response, while higher doses elicit a mixed Th1/Th2 response (Jiao et al., 2003). In addition, although BCG is delivered to infants intradermally, alternative delivery methods may enhance specific immune responses. For example, intranasal administration of BCG is a method of potentially inducing systemic and longlasting secretory immune responses (Langermann et al., 1994; Angelidou et al., 2020). Therefore in the future design of BCG-based vaccines, the availability of BCG substrains already in use in the target population, specific environmental factors, and administration techniques may all be important variables to account for (Castillo-Rodal et al., 2006).

BCG's ability to induce a robust Th1 response and non-specific immunomodulatory effects make it a successful "live-adjuvant" for combining with a variety of heterologous antigens. In the past, the direct co-administration of BCG mixed with an antigen of interest has been examined for protection against various diseases. For example, Pearce et al. have used paramyosin, an antigen derived from Schistosoma mansoni, for intradermal co-administration with BCG in mice. Partial protection of 26-33\% against $S$. mansoni challenge occurred when BCG was co-administered with only $4-40 \mu \mathrm{g}$ of the paramyosin antigen, while $2 \mathrm{mg}$ of the antigen alone was required to obtain the same level of protection. Protection occurred through the induction of a dominant Th1 response (Pearce et al., 1988; Sher et al., 1991). In a related study in sheep, co-administration of BCG and paramyosin leads to enhanced immunogenicity and up to $48 \%$ worm reduction compared to BCG alone (Taylor et al., 1998). Furthermore, the use of BCG as an adjuvant alongside various autoclaved Leishmania has proven to be a promising combination and is widely used in Leishmania vaccine (Dube et al., 1998; Misra et al., 2001; Nahrevanian et al., 2013). More recently, the progression of recombinant DNA technology has led to the utilization of BCG as a vaccine platform via genetic engineering approaches. Originally described in 1991 in a landmark paper by Stover et al., foreign genes of interest can now routinely be introduced into BCG through the use of E.coli-mycobacterium shuttle vectors, such that the encoded proteins are expressed extracellularly, intracellularly, or remain bound to the BCG cell surface (Stover et al., 1991; Zheng et al., 2015). In an attempt to maintain a stable level of expression of foreign antigens in BCG, the mycobacterial hsp60 promoter is most commonly included in plasmid expression vectors that are capable of integrating at the non-essential mycobacteriophage L5 attachment site (attB; Stover et al., 1991; Zheng et al., 2015). Lastly, optimization of foreign gene sequences based on the codon-usage preferences observed in Mycobacteria may also prove beneficial to maximize the level of heterologous gene expression (Varaldo et al., 2004).

\section{rBCG Applications and Approaches Anti-viral Vaccine Strategies}

rBCG vaccines have been designed using a wide range of viral, parasitic, and bacterial antigens including toxins. $\mathrm{rBCG}$ is a strong vaccine platform for viral diseases due to its ability to induce a strong Th1 response, which is ideal for clearing intracellular pathogens (Rosenthal and Zimmerman, 2006; Abarca et al., 2020). In HIV research, rBCG vaccines using HIV-specific antigens have been created to elicit virus-specific T-cell responses, generally using a prime-boost regimen. Priming with rBCG expressing HIV antigens and boosting with different vectors expressing HIV antigens appears to be favorable in HIV vaccine studies partially due to longer lasting immune effects - such as longer highly specific CTL responses - when compared to vaccinating with rBCG alone (Promkhatkaew et al., 2009a,b). For example, Kilpeläinen et al. primed BALB/c mice with rBCG expressing conserved HIV-1 mosaic immunogens and boosted them with simian adenovirus containing additional HIV-1 mosaic immunogens (Kilpeläinen et al., 2019). Inoculation was safe and led to the induction of HIV-1 specific IFN- $\gamma$ producing $\mathrm{T}$-cell responses and cytokine secretion, which were both significantly higher in the primed mice (Kilpeläinen et al., 2019). In addition, multiple rBCG vaccine constructs have been developed for testing against simian immunodeficiency (SIV) as a model for HIV disease. Many HIV researchers have used the gag polyprotein, which mediates vital viral assembly events, as an antigen due to its induction of cellular immunity (Jalalirad and Laughrea, 2010; Martins et al., 2014). Ami et al vaccinated cynomolgus macaques with rBCG and a replication-deficient vaccinia virus boost, both expressing full-length SIV gag (Ami et al., 2005). Upon challenge with a recombinant pathogenic simian-human immunodeficiency virus (SHIV KS661c), viral control, and effective long-lasting immunity through antigenspecific IFN- $\gamma$ production was only observed in the macaques primed with rBCG, but not the control groups (Ami et al., 2005). More recently, Kato et al primed cynomolgus monkeys with rBCG expressing SIV gag followed by a boost with SIV env or SIV pol expressing Vaccinia and a second boost with SIV env-expressing Sendai virus (Kato et al., 2020). Upon 
repeated challenge with SIVmac251, a pathogenic antibodyresistant (tier 2) SIV strain previously demonstrated to mimic HIV-1, plasma viremia was significantly lower, and in some cases undetectable (Kato et al., 2020). Moreover, high levels of potent CD8+ $\mathrm{T}$ cells were observed in vaccinated monkeys, but not the unvaccinated controls (Kato et al., 2020). Interestingly, the rBCG strain used here was urease-deficient, which seemed to increase immunogenicity against both BCG and SIV (Kato et al., 2020). Urease is involved in neutralization of the BCG-containing phagosome and urease-deficient BCG has been shown to be useful in T-cell activation by more efficiently producing memory $\mathrm{T}$ cells in $\mathrm{C} 57 \mathrm{BL} / 6$ mice, and potentially increasing presentation of BCG-derived antigens for CTL induction (Mukai et al., 2008; Nieuwenhuizen et al., 2017; Kato et al., 2020). Although substantial research has been focused on using rBCG for HIV, a number of other viral vaccine candidates are being created. A recent phase I clinical trial for an rBCG RSV vaccine conducted by Abarca et al demonstrated that participants could safely tolerate a rBCG-RSV vaccine containing the N protein of RSV (Abarca et al., 2020). The participants had serum IgG-antibodies specific to the RSV $\mathrm{N}$ protein, along with an increased cellular Th1 response specific to both the N protein and mycobacterial PPD (purified protein derivative; Abarca et al., 2020). Additional examples of viral candidate vaccines produced in the rBCG background include hepatitis C Virus (HCV; Wei et al., 2008) and human metapneumovirus (hMPV; Palavecino et al., 2014; Table 1).

\section{Anti-parasitic Vaccines}

$\mathrm{TB}$ is a leading cause of death in sub-Saharan Africa, where individuals are commonly co-infected with parasitic diseases (Brooker et al., 2006). Comorbidity between parasitic and bacterial diseases creates a contrasting scenario since helminths tend to induce strong Th2 responses, while TB induces a Th1-biased response (Cozmei et al., 2007; Cadmus et al., 2020). This situation creates a potential challenge for the development of $\mathrm{rBCG}$ protecting against both infant TB and parasitic diseases. Malaria, a life-threatening disease caused by the apicomplexan parasite Plasmodium falciparum, has been targeted by rBCG vaccines. For example, a study conducted by Arama et al immunized $\mathrm{BALB} / \mathrm{c}$ mice with $\mathrm{rBCG}$ expressing the $P$. falciparum circumsporozoite protein (CSp) and observed an upregulation of MHCII activation, along with CSp-specific IFN- $\gamma$ producing memory cells and antibodies (Arama et al., 2012). Mice inoculated with a homologous BCG-CSp prime-boost regimen had the most robust Th1 response, characterized by higher levels of IgG2a antibodies compared to the homologous CSp/CSp recombinant protein group (Arama et al., 2012). However, this vaccine's efficacy against $P$. falciparum challenge has yet to be documented in mice (Arama et al., 2012; Minkah et al., 2018). As previously mentioned, vaccines have been developed for Schistosoma by co-administrating BCG with a Schistosoma antigen, such as paramyosin and Sm23 (Pearce et al., 1988; Taylor et al., 1998). More recently, rBCG expressing the Sm14 antigen (a fatty-acid binding protein) from $S$. mansoni has been created and proven to induce a predominantly Th1-type-response in BALB/c or Swiss mice (Varaldo et al., 2004). Furthermore, one or two doses of the rBCG vaccine conferred a $48 \%$ reduction in worm burden upon challenge, which was comparable to three doses of the purified rSm14 antigen (Varaldo et al., 2004). Although rBCG induces a predominantly Th1-type-response, Th2 responses may still be observed with rBCG parasitic vaccines. In the case of Toxoplasma gondii, an opportunistic protozoan parasite causing severe toxoplasmosis in humans and livestock, following vaccination with BCG expressing T. gondii cyclophilin (TgCyP) - a nitric oxide inducing protein vital for the $T$. gondii life cycle (Ibrahim et al., 2009) - both Th1 and Th2 responses were observed in $\mathrm{BALB} / \mathrm{c}$ mice prior to pathogenic T. gondii challenge (Yu et al., 2013). Although the Th1 response was much higher in the rBCG vaccinated groups, Th2 responses were equivalent in control (PBS or BCG) and rBCG groups (Yu et al., 2013). Therefore, rBCG vaccination may be able to induce an enhanced Th1 response without reducing or interfering with the critical Th2 responses naturally induced against parasitic infections (Yu et al., 2013). However, a limited protection of only $17 \%$ was reached in these vaccinated mice when challenged with T. gondii (Yu et al., 2013). Targeting parasitic proteins through rBCG have also been analyzed for Trypanosoma cruzi and Eimeria maxima (Li et al., 2013; Bontempi et al., 2020; Table 1).

\section{Anti-bacterial and Anti-toxin Strategies}

Several bacterial antigens have also been expressed in BCG in an attempt to induce immunity. A recent study by Dorneles et al used various combinations of Leptospira antigens to target the zoonotic bacterial disease leptospirosis (Dorneles et al., 2020). Upon subcutaneous inoculation of hamsters with four rBCG constructs, each encoding a distinct portion of a recombinant chimera made of various leptospiral antigens, all constructs provided full protection against leptospirosis challenge through the induction of cellular immune responses, in contrast to the BCG controls which had no protection (Dorneles et al., 2020). However, rBCG anti-bacterial vaccines have also been shown to elicit strong humoral responses. For example, in one of the earliest descriptions using BCG as a vaccine platform, an $\mathrm{rBCG}$ vaccine expressing the OspA outer surface protein antigen of Borrelia burgdorferi was shown to generate high titer antibody responses across a diverse set of heterogeneous mouse strains (Stover et al., 1993). Furthermore, this protective antibody response was observed to be 100-1,000-fold higher when OspA was expressed as a membrane-associated lipoprotein, compared to cytoplasmic or secreted forms of the same protein (Stover et al., 1993). Additional bacterial diseases whose toxins or antigens have been expressed within rBCG strains include Shiga toxin-producing E. coli (STEC) and Bordetella pertussis (Nascimento et al., 2009; Fujii et al., 2012). Both vaccines induced high levels of protection against bacterial challenge through differing immune responses. In the case of the rBCG STEC vaccine, protection against STEC oral challenge was observed through humoral immunity, specifically the induction of protective serum IgG and mucosal IgA responses (Fujii et al., 2012). However for the rBCG-Pertussis vaccine, a predominantly cellular Th1 response involving IFN- $\gamma$ and TNF- $\alpha$ release was 
TABLE 1 | rBCG vaccine candidates and their immune responses against various viral, parasitic, or bacterial challenges.

\begin{tabular}{|c|c|c|c|c|c|c|c|}
\hline & Infection & BCG strain & $\begin{array}{l}\text { Gene(s)/Protein(s) } \\
\text { expressed }\end{array}$ & $\begin{array}{l}\text { Additional } \\
\text { antigen details }\end{array}$ & Animal model & $\begin{array}{l}\text { Type(s) of immune } \\
\text { response noted }\end{array}$ & References \\
\hline \multirow[t]{7}{*}{ Viral } & $\begin{array}{l}\text { Human } \\
\text { immunodeficiency } \\
\text { virus } 1 \text { (HIV-1) }\end{array}$ & $\begin{array}{l}\text { Danish and } \\
\text { Connaught }\end{array}$ & $\begin{array}{l}\text { HIVconsv1\&2 } \\
\text { immunogens along } \\
\text { with ChAdOx1. } \\
\text { tHIVconsv5\&6 } \\
\text { (conserved HIV-1 } \\
\text { mosaic immunogens) }\end{array}$ & $\begin{array}{l}\text { Mtb19-kDa } \\
\text { lipoprotein signal } \\
\text { sequence }\end{array}$ & BALB/c mice & $\begin{array}{l}\text { Cellular: Increased } \\
\text { induction of IFN- } \gamma \text { and } \\
\text { TNF- } \alpha, \text { CD } 4+\text { and CD8+ } \\
\text { CTLs. }\end{array}$ & $\begin{array}{l}\text { Kilpeläinen et al., } \\
2019\end{array}$ \\
\hline & $\begin{array}{l}\text { Simian } \\
\text { immunodeficiency } \\
\text { virus (SIV) }\end{array}$ & Tokyo & SIVgag polyprotein & $\begin{array}{l}\alpha \text { antigen, } \\
\text { extracellular } \\
\text { secretion of fusion } \\
\text { protein }\end{array}$ & $\begin{array}{l}\text { Male cynomolgus } \\
\text { macaques } \\
\text { (Macaca } \\
\text { fascicularis) }\end{array}$ & $\begin{array}{l}\text { Prime-boost inoculation } \\
\text { of rBCG-SIVgag followed } \\
\text { by rDIsSIVgag lead to } \\
\text { cellular responses } \\
\text { through increased IFN- } \gamma \\
\text { and immunity against } \\
\text { SHIV challenge for one } \\
\text { year. }\end{array}$ & Ami et al., 2005 \\
\hline & & Tokyo & $\begin{array}{l}\text { SIV proteins: Gag, } \\
\text { Env gp120 and a } \\
\text { fusion protein of Rev, } \\
\text { Tat and Nef (RTN) } \\
\text { proteins }\end{array}$ & $\begin{array}{l}\text { Urease-deficient } \\
\text { BCG expressing } \\
\text { SIV genes }\end{array}$ & $\begin{array}{l}\text { Male cynomolgus } \\
\text { macaques }\end{array}$ & $\begin{array}{l}\text { Cellular: little to no } \\
\text { plasma viremia detected, } \\
\text { along with high levels of } \\
\text { potent CD8+ T cells were } \\
\text { observed, and partial or } \\
\text { full protection from } \\
\text { challenge. }\end{array}$ & Kato et al., 2020 \\
\hline & $\begin{array}{l}\text { Hepatitis C virus } \\
\text { (HCV) }\end{array}$ & Tokyo & $\begin{array}{l}\text { CtEm, a multi-epitope } \\
\text { antigen composed of } \\
\text { HCV structural and } \\
\text { non-structural } \\
\text { epitopes }\end{array}$ & $\begin{array}{l}\text { Signal peptide } \\
\alpha \text {-ss antigen } \\
\text { derived from } \\
\text { H37Rv Mtb, } \\
\text { secreted CtEm } \\
\text { protein }\end{array}$ & $\begin{array}{l}\mathrm{HLA}-\mathrm{A} 2.1 \\
\text { transgenic mice }\end{array}$ & $\begin{array}{l}\text { Th1 dominant cellular } \\
\text { response and induction } \\
\text { of specific anti-HCV } \\
\text { antibodies. Protection } \\
\text { against recombinant } \\
\text { vaccinia virus (rV-HCV- } \\
\text { CNS) was observed in } \\
\text { vivo. }\end{array}$ & Wei et al., 2008 \\
\hline & $\begin{array}{l}\text { Human } \\
\text { metapneumovirus } \\
\text { (hMPV) }\end{array}$ & Danish & $\begin{array}{l}\text { M2-1 (participates in } \\
\text { viral transcriptional } \\
\text { regulation) and } \\
\text { hMPV-P } \\
\text { (phosphoprotein) }\end{array}$ & & BALB/c mice & $\begin{array}{l}\text { Th1 dominant response, } \\
\text { induction of hMPV- } \\
\text { specific T cells producing } \\
\text { IFN- } \gamma \text { and IL-2, } \\
\text { immunized mice were } \\
\text { protected against } \\
\text { disease symptoms and } \\
\text { viral replication in the } \\
\text { lungs. }\end{array}$ & $\begin{array}{l}\text { Palavecino et al., } \\
2014\end{array}$ \\
\hline & $\begin{array}{l}\text { Respiratory syncytial } \\
\text { virus (RSV) }\end{array}$ & Danish & RSV nucleoprotein (N) & & $\begin{array}{l}\text { Phase I clinical } \\
\text { trial: } 24 \text { healthy } \\
\text { males aged } \\
\text { 19-44 }\end{array}$ & $\begin{array}{l}\text { Serum IgG-antibodies } \\
\text { directed against } \\
\text { Mycobacterium and RSV } \\
\mathrm{N} \text { protein, induced after } \\
\text { vaccination and } \\
\text { neutralized RSV in vitro. } \\
\text { Increased IFN- } \gamma \text { and IL-2 } \\
\text { also observed. }\end{array}$ & $\begin{array}{l}\text { Bueno et al., } \\
\text { 2008; Abarca } \\
\text { et al., } 2020\end{array}$ \\
\hline & Rotavirus & $\begin{array}{l}\text { Tokyo and } \\
\text { Pasteur }\end{array}$ & $\begin{array}{l}\text { VP6 (immunogenic } \\
\text { intermediate-layer } \\
\text { capsid protein) }\end{array}$ & $\begin{array}{l}\text { Mtb19-kDa } \\
\text { lipoprotein signal } \\
\text { sequence, VP6 } \\
\text { linked to BCG cell } \\
\text { membrane }\end{array}$ & BALB/c mice & $\begin{array}{l}\text { Up to } 66 \% \text { reduction in } \\
\text { fecal viral shedding } \\
\text { compared to controls } \\
\text { upon rotavirus challenge. } \\
\text { No anti-rotavirus } \\
\text { antibody was detected, } \\
\text { meaning antigen-specific } \\
\text { CD4+ or CD8+ T cells are } \\
\text { most likely mediators of } \\
\text { protection from viral } \\
\text { infection. }\end{array}$ & $\begin{array}{l}\text { Dennehy et al., } \\
2007\end{array}$ \\
\hline
\end{tabular}


TABLE 1 | Continued

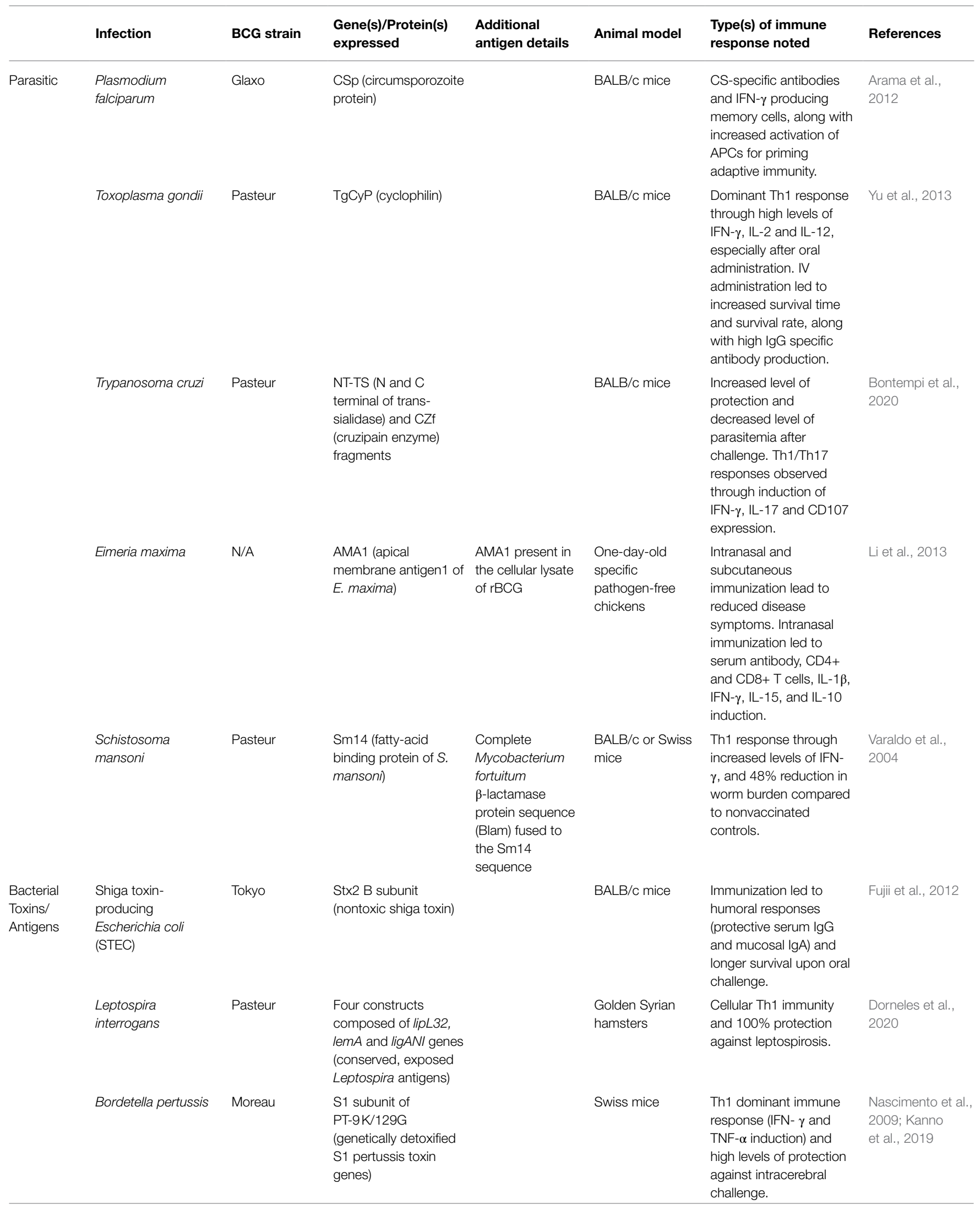


TABLE 1 | Continued

\begin{tabular}{|c|c|c|c|c|c|c|}
\hline Infection & BCG strain & $\begin{array}{l}\text { Gene(s)/Protein(s) } \\
\text { expressed }\end{array}$ & $\begin{array}{l}\text { Additional } \\
\text { antigen details }\end{array}$ & Animal model & $\begin{array}{l}\text { Type(s) of immune } \\
\text { response noted }\end{array}$ & References \\
\hline Borrelia burgdorferi & Pasteur & $\begin{array}{l}\text { Outer surface protein } \\
\mathrm{A}(\mathrm{OspA})\end{array}$ & $\begin{array}{l}\text { Mtb19-kDa } \\
\text { lipoprotein signal } \\
\text { sequence, OspA } \\
\text { expressed as a } \\
\text { membrane- } \\
\text { associated } \\
\text { lipoprotein }\end{array}$ & $\begin{array}{l}\text { Swiss, BALB/c, } \\
\text { or C3H/HeJ mice }\end{array}$ & $\begin{array}{l}100-1,000 \text {-fold higher } \\
\text { protective antibody } \\
\text { response when } \\
\text { expressed as a } \\
\text { membrane-associated } \\
\text { lipoprotein when } \\
\text { compared to cytoplasmic } \\
\text { or secreted protein } \\
\text { expression. }\end{array}$ & $\begin{array}{l}\text { Stover et al., } \\
1993\end{array}$ \\
\hline
\end{tabular}

associated with protection against lethal intracerebral challenge of B. pertussis in neonate mice (Nascimento et al., 2009). Therefore, rBCG can elicit lasting humoral and cellular immunity for various foreign bacterial antigens (Zheng et al., 2015).

\section{DISCUSSION}

BCG is an extremely advantageous platform for vaccine development due to its long-history of being safe to use (it is approved for use in many countries worldwide), its stability, and ease of distribution, and it is a live-vaccine vehicle that provides sustained cellular immune responses. It also serves as an effective adjuvant by enhancing immunogenicity above that seen with just the antigen alone (Varaldo et al., 2004; Zheng et al., 2015) and is capable of "off-target" immune enhancing effects including trained immunity (Vierboom et al., 2021). When employing rBCG, surface expression or secretion of the protein of interest appears to be critical, partially due to increases in antigen presentation and improved cross-priming, both leading to increased cellular immunity (Deres et al., 1989; Reitermann et al., 1989; Grode et al., 2005; Sali et al., 2010). Therefore, as noted above and in Table 1, signal sequences, such as those derived from Ag85B and the $19 \mathrm{kDa}$ antigen, are commonly fused to the foreign genes of interest (Garbe et al., 1993; Gomez et al., 2000; Sixsmith et al., 2014; Oliveira et al., 2017). In many instances, it may be ideal to choose a signal sequence which utilizes the general secretory pathway (Bendtsen et al., 2005). The latter may be favorable since it transports proteins in an unfolded state, thus limiting the creation of non-functional misfolded and aggregated proteins and does not require the action of chaperone proteins or accessory molecules (Feltcher et al., 2010). Bacterial lipoprotein signal sequences, such as that associated with the $19 \mathrm{kDa}$ lipoprotein $(\mathrm{LpqH})$, have also been used in rBCG research due to their strongly immunogenic properties (Stover et al., 1993; Dennehy et al., 2007). For example, an anti-rotavirus vaccine expressing VP6 only induced significant cellular immunity-based protection when linked to the $19 \mathrm{kDa}$ lipoprotein signal sequence that allowed transport of VP6 to the BCG outer membrane (Dennehy et al., 2007).

One potential limitation in the use of rBCG technology exists in the use of E. coli-mycobacterium shuttle vectors to transfer foreign genes of interest into BCG. These plasmids commonly contain an antibiotic resistance gene as a selectable marker. However, vaccines containing antibiotic genes are largely unsuitable for human use, predominantly due to the potential risk of horizontal transfer of antibiotic resistance to nearby microbial populations (Borsuk et al., 2007; Mignon et al., 2015). Therefore, methods, such as Cre-lox recombination, have been explored to subsequently remove antibiotic resistance markers following transformation and selection. Cre-lox recombination systems are very efficient for multiple gene replacements but to the best of our knowledge have yet to be applied to rBCG development, although they have been used in other Mycobacteria (Lambert et al., 2007; Murphy et al., 2015; Hurst-Hess et al., 2017). Alternate selection methods, such as auxotrophic complementation, allow in vivo selection in the absence of antibiotics through the use of a BCG strain that, for example, is auxotrophic for leucine (leuD knockout) in conjunction with a plasmid vector containing leuD that is then used to introduce the foreign antigen of interest (Borsuk et al., 2007). The creation of an unmarked rBCG vaccine in this manner has been described by Nascimento et al. (2009). In this particular study, a rBCG-pertussis vaccine, which elicited protection against $B$. pertussis challenge in mice, was generated through auxotrophic complementation based on lysine rather than leucine (Nascimento et al., 2009).

In summary, BCG has been shown to provide protection against a large range of infections beyond $\mathrm{TB}$, including both bacterial and viral respiratory infections (Fine, 1995; Zheng et al., 2015). Even in the context of the current COVID-19 pandemic, a correlation has been suggested between COVID-19 case fatality rates and national rates of BCG vaccination (Rivas et al., 2021). Although it remains to be proven, protection against SARS-CoV-2 could potentially be associated with BCG's trained immunity and non-specific Th1 responses, in line with its ability to reduce other respiratory tract infections in children (Rivas et al., 2021). In theory, any anti-SARS-CoV-2 activity displayed by BCG could potentially be enhanced by creating a novel rBCG-based vaccine candidate that expresses one or more protein components of the SARS-CoV-2 virus (Krammer, 2020) and our group is currently exploring this line of inquiry.

In conclusion, the use of BCG for a variety of vaccination purposes - both specific and non-specific - has opened the door for renewed enthusiasm to further explore the use of $\mathrm{rBCG}$ vaccine technology in future vaccine development and immunotherapy. 


\section{AUTHOR CONTRIBUTIONS}

EM performed the literature searches and wrote the manuscript. $\mathrm{MR}, \mathrm{PD}$, and $\mathrm{MN}$ contributed to the writing and editing. All authors contributed to the article and approved the submitted version.

\section{REFERENCES}

Abarca, K., Rey-Jurado, E., Muñoz-Durango, N., Vázquez, Y., Soto, J. A., Gálvez, N. M. S., et al. (2020). Safety and immunogenicity evaluation of recombinant BCG vaccine against respiratory syncytial virus in a randomized, double-blind, placebo-controlled phase I clinical trial. E. Clinical. Medicine 27:100517. doi: 10.1016/j.eclinm.2020.100517

Ami, Y., Izumi, Y., Matsuo, K., Someya, K., Kanekiyo, M., Horibata, S., et al. (2005). Priming-boosting vaccination with recombinant Mycobacterium bovis bacillus Calmette-Guerin and a nonreplicating vaccinia virus recombinant leads to long-lasting and effective immunity. J. Virol. 79, 12871-12879. doi: 10.1128/JVI.79.20.12871-12879.2005

Angelidou, A., Diray-Arce, J., Conti, M. G., Smolen, K. K., van Haren, S. D., Dowling, D. J., et al. (2020). BCG as a case study for precision vaccine development: lessons From vaccine heterogeneity, trained immunity, and immune ontogeny. Front. Microbiol. 11:332. doi: 10.3389/fmicb.2020.00332

Arama, C., Waseem, S., Fernández, C., Assefaw-Redda, Y., You, L., Rodriguez, A., et al. (2012). A recombinant Bacille Calmette-Guérin construct expressing the plasmodium falciparum circumsporozoite protein enhances dendritic cell activation and primes for circumsporozoite-specific memory cells in BALB/c mice. Vaccine 30, 5578-5584. doi: 10.1016/j.vaccine.2011.09.054

Behr, M. A., and Small, P. M. (1999). A historical and molecular phylogeny of BCG strains. Vaccine 17, 915-922. doi: 10.1016/S0264-410X(98)00277-1

Bendtsen, J. D., Kiemer, L., Fausbøll, A., and Brunak, S. (2005). Non-classical protein secretion in bacteria. BMC Microbiol. 5:58. doi: 10.1186/1471-2180-5-58

Bontempi, I., Leal, K., Prochetto, E., Díaz, G., Cabrera, G., Bortolotti, A., et al. (2020). Recombinant Mycobacterium bovis BCG is a promising platform to develop vaccines against Trypansoma cruzi infection. Clin. Exp. Immunol. 201, 306-316. doi: 10.1111/cei.13469

Borsuk, S., Mendum, T. A., Fagundes, M. Q., Michelon, M., Cunha, C. W., McFadden, J., et al. (2007). Auxotrophic complementation as a selectable marker for stable expression of foreign antigens in Mycobacterium bovis BCG. Tuberculosis (Edinb.) 87, 474-480. doi: 10.1016/j.tube.2007.07.006

Brooker, S., Clements, A. C., and Bundy, D. A. (2006). Global epidemiology, ecology and control of soil-transmitted helminth infections. Adv. Parasitol. 62, 221-261. doi: 10.1016/s0065-308x(05)62007-6

Bueno, S. M., González, P. A., Cautivo, K. M., Mora, J. E., Leiva, E. D., Tobar, H. E., et al. (2008). Protective T cell immunity against respiratory syncytial virus is efficiently induced by recombinant BCG. Proc. Natl. Acad. Sci. U. S. A. 105, 20822-20827. doi: 10.1073/pnas.0806244105

Cadmus, S. I., Akinseye, V. O., Taiwo, B. O., Pinelli, E. O., van Soolingen, D., and Rhodes, S. G. (2020). Interactions between helminths and tuberculosis infections: implications for tuberculosis diagnosis and vaccination in Africa. PLoS Negl. Trop. Dis. 14:e0008069. doi: 10.1371/journal.pntd.0008069

Castillo-Rodal, A. I., Castañón-Arreola, M., Hernández-Pando, R., Calva, J. J., Sada-Díaz, E., and López-Vidal, Y. (2006). Mycobacterium bovis BCG substrains confer different levels of protection against mycobacterium tuberculosis infection in a BALB/c model of progressive pulmonary tuberculosis. Infect. Immun. 74, 1718-1724. doi: 10.1128/IAI.74.3.1718-1724.2006

Conrad, W. H., Osman, M. M., Shanahan, J. K., Chu, F., Takaki, K. K., Cameron, J., et al. (2017). Mycobacterial ESX-1 secretion system mediates host cell lysis through bacterium contact-dependent gross membrane disruptions. Proc. Natl. Acad. Sci. U. S. A. 114, 1371-1376. doi: 10.1073/ pnas. 1620133114

Covián, C., Fernández-Fierro, A., Retamal-Díaz, A., Díaz, F. E., Vasquez, A. E., Lay, M. K., et al. (2019). BCG-induced cross-protection and development of trained immunity: implication for vaccine design. Front. Immunol. 10:2806. doi: 10.3389/fimmu.2019.02806

Cozmei, C., Constantinescu, D., Carasevici, E., Anisie, E., Ungureanu, D., Sorete-Arbore, A., et al. (2007). Th1 and Th2 cytokine response in patients

\section{FUNDING}

This manuscript was supported by funding obtained from the McGill Interdisciplinary Initiative in Infection and Immunity (MI4; ECRF-R2-70).

with pulmonary tuberculosis and health care workers occupationally exposed to M. tuberculosis. Rev. Med. Chir. Soc. Med. Nat. Iasi. 111, 702-709

Dennehy, M., Bourn, W., Steele, D., and Williamson, A. L. (2007). Evaluation of recombinant BCG expressing rotavirus VP6 as an anti-rotavirus vaccine. Vaccine 25, 3646-3657. doi: 10.1016/j.vaccine.2007.01.087

Deres, K., Schild, H., Wiesmüller, K.-H., Jung, G., and Rammensee, H.-G. (1989). In vivo priming of virus-specific cytotoxic $\mathrm{T}$ lymphocytes with synthetic lipopeptide vaccine. Nature 342, 561-564. doi: 10.1038/342561a0

Dorneles, J., Madruga, A. B., Seixas Neto, A. C. P., Rizzi, C., Bettin, É. B., Hecktheuer, A. S., et al. (2020). Protection against leptospirosis conferred by Mycobacterium bovis BCG expressing antigens from Leptospira interrogans. Vaccine 38, 8136-8144. doi: 10.1016/j.vaccine.2020.10.086

Dube, A., Sharma, P., Srivastava, J. K., Misra, A., Naik, S., and Katiyar, J. C. (1998). Vaccination of langur monkeys (Presbytis entellus) against Leishmania donovani with autoclaved L. major plus BCG. Parasitology 116, 219-221. doi: 10.1017/S0031182097002175

Feltcher, M. E., Sullivan, J. T., and Braunstein, M. (2010). Protein export systems of mycobacterium tuberculosis: novel targets for drug development? Future Microbiol. 5, 1581-1597. doi: 10.2217/fmb.10.112

Fine, P. E. M. (1995). Variation in protection by BCG: implications of and for heterologous immunity. Lancet 346, 1339-1345. doi: 10.1016/ S0140-6736(95)92348-9

Fujii, J., Naito, M., Yutsudo, T., Matsumoto, S., Heatherly, D. P., Yamada, T., et al. (2012). Protection by a recombinant Mycobacterium bovis bacillus Calmette-Guerin vaccine expressing Shiga toxin 2 B subunit against Shiga toxin-producing Escherichia coli in mice. Clin. Vaccine Immunol. 19, 1932-1937. doi: 10.1128/CVI.00473-12

Garbe, T., Harris, D., Vordermeier, M., Lathigra, R., Ivanyi, J., and Young, D. (1993). Expression of the mycobacterium tuberculosis 19-kilodalton antigen in mycobacterium smegmatis: immunological analysis and evidence of glycosylation. Infect. Immun. 61, 260-267. doi: 10.1128/iai.61.1.260-267.1993

Gomez, M., Johnson, S., and Gennaro, M. L. (2000). Identification of secreted proteins of mycobacterium tuberculosis by a bioinformatic approach. Infect. Immun. 68, 2323-2327. doi: 10.1128/IAI.68.4.2323-2327.2000

Grode, L., Seiler, P., Baumann, S., Hess, J., Brinkmann, V., Nasser Eddine, A., et al. (2005). Increased vaccine efficacy against tuberculosis of recombinant Mycobacterium bovis bacille Calmette-Guérin mutants that secrete listeriolysin. J. Clin. Invest. 115, 2472-2479. doi: 10.1172/JCI24617

Hurst-Hess, K., Rudra, P., and Ghosh, P. (2017). Mycobacterium abscessus WhiB7 regulates a species-specific repertoire of genes to confer extreme antibiotic resistance. Antimicrob. Agents Chemother. 61, e01347-e01317. doi: 10.1128/AAC.01347-17

Ibrahim, H. M., Bannai, H., Xuan, X., and Nishikawa, Y. (2009). Toxoplasma gondii cyclophilin 18-mediated production of nitric oxide induces Bradyzoite conversion in a CCR5-dependent manner. Infect. Immun. 77, 3686-3695. doi: 10.1128/IAI.00361-09

Jalalirad, M., and Laughrea, M. (2010). Formation of immature and mature genomic RNA dimers in wild-type and protease-inactive HIV-1: differential roles of the gag polyprotein, nucleocapsid proteins NCp15, NCp9, NCp7, and the dimerization initiation site. Virology 407, 225-236. doi: 10.1016/j. virol.2010.08.013

Jiao, X., Lo-Man, R., Winter, N., Dériaud, E., Gicquel, B., and Leclerc, C. (2003). The shift of Th1 to Th2 Immunodominance associated with the chronicity of Mycobacterium bovis Bacille Calmette-Guérin infection does not affect the memory response. J. Immunol. 170, 1392-1398. doi: 10.4049/ jimmunol.170.3.1392

Kanno, A. I., Goulart, C., Leite, L. C. C., Pagliarone, A. C., and Nascimento, I. P. (2019). A bivalent recombinant Mycobacterium bovis BCG expressing the S1 subunit of the pertussis toxin induces a Polyfunctional CD4(+) T cell immune response. Biomed. Res. Int. 2019:9630793. doi: 10.1155/2019/9630793 
Kato, S., Shida, H., Okamura, T., Zhang, X., Miura, T., Mukai, T., et al. (2020). CD8 $\mathrm{T}$ cells show protection against highly pathogenic simian immunodeficiency virus (SIV) after vaccination with SIV gene-expressing BCG prime and vaccinia virus/Sendai virus vector boosts. J. Virol. 95, 01718-01720. doi: 10.1128/JVI.01718-20

Kilpeläinen, A., Saubi, N., Guitart, N., Moyo, N., Wee, E. G., Ravi, K., et al. (2019). Priming With recombinant BCG expressing novel HIV-1 conserved mosaic Immunogens and boosting With recombinant ChAdOxl is safe, stable, and elicits HIV-1-specific T-cell responses in BALB/c mice. Front. Immunol. 10:923. doi: 10.3389/fimmu.2019.00923

Kleinnijenhuis, J., Quintin, J., Preijers, F., Joosten, L. A., Ifrim, D. C., Saeed, S., et al. (2012). Bacille Calmette-Guerin induces NOD2-dependent nonspecific protection from reinfection via epigenetic reprogramming of monocytes. Proc. Natl. Acad. Sci. U. S. A. 109, 17537-17542. doi: 10.1073/pnas. 1202870109

Kleinnijenhuis, J., van Crevel, R., and Netea, M. G. (2015). Trained immunity: consequences for the heterologous effects of BCG vaccination. Trans. $R$. Soc. Trop. Med. Hyg. 109, 29-35. doi: 10.1093/trstmh/trul68

Krammer, F. (2020). SARS-CoV-2 vaccines in development. Nature 586, 516-527. doi: $10.1038 /$ s41586-020-2798-3

Lambert, J. M., Bongers, R. S., and Kleerebezem, M. (2007). Cre-lox-based system for multiple gene deletions and selectable-marker removal in lactobacillus plantarum. Appl. Environ. Microbiol. 73, 1126-1135. doi: 10.1128/AEM. 01473-06

Langermann, S., Palaszynski, S., Sadziene, A., Stover, C. K., and Koenig, S. (1994). Systemic and mucosal immunity induced by BCG vector expressing outer-surface protein A of Borrelia burgdorferi. Nature 372, 552-555. doi: $10.1038 / 372552 \mathrm{a} 0$

Li, W. C., Zhang, X. K., Du, L., Pan, L., Gong, P. T., Li, J. H., et al. (2013). Eimeria maxima: efficacy of recombinant Mycobacterium bovis BCG expressing apical membrane antigen1 against homologous infection. Parasitol. Res. 112, 3825-3833. doi: 10.1007/s00436-013-3570-5

Mahairas, G. G., Sabo, P. J., Hickey, M. J., Singh, D. C., and Stover, C. K. (1996). Molecular analysis of genetic differences between Mycobacterium bovis BCG and virulent M. bovis. J. Bacteriol. 178, 1274-1282. doi: 10.1128/ jb.178.5.1274-1282.1996

Majlessi, L., Brodin, P., Brosch, R., Rojas, M.-J., Khun, H., Huerre, M., et al. (2005). Influence of ESAT-6 secretion system 1 (RD1) of mycobacterium tuberculosis on the interaction between mycobacteria and the host immune system. J. Immunol. 174, 3570-3579. doi: 10.4049/jimmunol.174.6.3570

Martins, M. A., Wilson, N. A., Piaskowski, S. M., Weisgrau, K. L., Furlott, J. R., Bonaldo, M. C., et al. (2014). Vaccination with gag, Vif, and Nef gene fragments affords partial control of viral replication after mucosal challenge with SIVmac239. J. Virol. 88, 7493-7516. doi: 10.1128/JVI.00601-14

Mignon, C., Sodoyer, R., and Werle, B. (2015). Antibiotic-free selection in biotherapeutics: now and forever. Pathogens 4, 157-181. doi: 10.3390/ pathogens 4020157

Milstien, J. B., and Gibson, J. J. (1990). Quality control of BCG vaccine by WHO: a review of factors that may influence vaccine effectiveness and safety. Bull. World Health Organ. 68, 93-108

Minkah, N. K., Schafer, C., and Kappe, S. H. I. (2018). Humanized mouse models for the study of human malaria parasite biology, pathogenesis, and immunity. Front. Immunol. 9:807. doi: 10.3389/fimmu.2018.00807

Misra, A., Dube, A., Srivastava, B., Sharma, P., Srivastava, J. K., Katiyar, J. C., et al. (2001). Successful vaccination against Leishmania donovani infection in Indian langur using alum-precipitated autoclaved Leishmania major with BCG. Vaccine 19, 3485-3492. doi: 10.1016/S0264-410X(01)00058-5

Mukai, T., Maeda, Y., Tamura, T., Miyamoto, Y., and Makino, M. (2008). CD4+ T-cell activation by antigen-presenting cells infected with urease-deficient recombinant Mycobacterium bovis bacillus Calmette-Guérin. FEMS Immunol. Med. Microbiol. 53, 96-106. doi: 10.1111/j.1574-695X.2008.00407.x

Murphy, K. C., Papavinasasundaram, K., and Sassetti, C. M. (2015). "Mycobacterial Recombineering," in Mycobacteria Protocols. eds. T. Parish and D. M. Roberts (New York, NY: Springer New York), 177-199.

Nahrevanian, H., Jafary, P. S., Nemati, S., Farahmand, M., and Omidinia, E. (2013). Evaluation of anti-leishmanial effects of killed Leishmania vaccine with BCG adjuvant in BALB/c mice infected with Leishmania major MRHO/ IR/75/ER. Folia Parasitol. 60, 1-6. doi: 10.14411/fp.2013.001

Nascimento, I. P., Dias, W. O., Quintilio, W., Hsu, T., Jacobs, W. R. Jr., and Leite, L. C. (2009). Construction of an unmarked recombinant BCG expressing a pertussis antigen by auxotrophic complementation: protection against Bordetella pertussis challenge in neonates. Vaccine 27, 7346-7351. doi: 10.1016/j.vaccine.2009.09.043

Nemes, E., Geldenhuys, H., Rozot, V., Rutkowski, K. T., Ratangee, F., Bilek, N., et al. (2018). Prevention of M. tuberculosis infection with H4:IC31 vaccine or BCG revaccination. N. Engl. J. Med. 379, 138-149. doi: 10.1056/ NEJMoa1714021

Nieuwenhuizen, N. E., Kulkarni, P. S., Shaligram, U., Cotton, M. F., Rentsch, C. A., Eisele, B., et al. (2017). The recombinant Bacille Calmette-Guérin vaccine VPM1002: ready for clinical efficacy testing. Front. Immunol. 8:1147. doi: 10.3389/fimmu.2017.01147

O’Neill, L. A. J., and Netea, M. G. (2020). BCG-induced trained immunity: can it offer protection against COVID-19? Nat. Rev. Immunol. 20, 335-337. doi: 10.1038/s41577-020-0337-y

Oliveira, T. L., Rizzi, C., and Dellagostin, O. A. (2017). Recombinant BCG vaccines: molecular features and their influence in the expression of foreign genes. Appl. Microbiol. Biotechnol. 101, 6865-6877. doi: 10.1007/ s00253-017-8439-6

Palavecino, C. E., Céspedes, P. F., Gómez, R. S., Kalergis, A. M., and Bueno, S. M. (2014). Immunization with a recombinant bacillus Calmette-Guerin strain confers protective Th1 immunity against the human metapneumovirus. J. Immunol. 192, 214-223. doi: 10.4049/jimmunol.1300118

Pearce, E. J., James, S. L., Hieny, S., Lanar, D. E., and Sher, A. (1988). Induction of protective immunity against Schistosoma mansoni by vaccination with schistosome paramyosin (Sm97), a nonsurface parasite antigen. Proc. Natl. Acad. Sci. U. S. A. 85, 5678-5682. doi: 10.1073/pnas.85.15.5678

Promkhatkaew, D., Matsuo, K., Pinyosukhee, N., Thongdeejaroen, W., Leang-aramgul, P., Sawanpanyalert, P., et al. (2009a). Prime-boost vaccination using recombinant Mycobacterium bovis BCG and recombinant vaccinia virus DIs harboring HIV-1 CRF01_AE gag in mice: influence of immunization routes. Southeast Asian J. Trop. Med. Public Health 40, 273-281

Promkhatkaew, D., Pinyosukhee, N., Thongdeejaroen, W., Sutthent, R., Sawanpanyalert, P., and Warachit, P. (2009b). Enhancement of cell-mediated immune response in mice by whole HIV-1 gag in Mycobacterium bovis BCG as a live vaccine candidate. Southeast Asian J. Trop. Med. Public Health $40,113-122$

Reitermann, A., Metzger, J., Wiesmüller, K. H., Jung, G., and Bessler, W. G. (1989). Lipopeptide derivatives of bacterial lipoprotein constitute potent immune adjuvants combined with or covalently coupled to antigen or hapten Biol. Chem. Hoppe Seyler 370, 343-352. doi: 10.1515/bchm3.1989.370.1.343

Rivas, M. N., Ebinger, J. E., Wu, M., Sun, N., Braun, J., Sobhani, K., et al. (2021). BCG vaccination history associates with decreased SARS-CoV-2 seroprevalence across a diverse cohort of health care workers. J. Clin. Invest. 131. doi: $10.1172 / \mathrm{JCI} 145157$

Rosenthal, K. S., and Zimmerman, D. H. (2006). Vaccines: all things considered. Clin. Vaccine Immunol. 13, 821-829. doi: 10.1128/CVI.00152-06

Sali, M., Di Sante, G., Cascioferro, A., Zumbo, A., Nicolò, C., Donà, V., et al. (2010). Surface expression of MPT64 as a fusion with the PE domain of PE_PGRS33 enhances Mycobacterium bovis BCG protective activity against mycobacterium tuberculosis in mice. Infect. Immun. 78, 5202-5213. doi: 10.1128/IAI.00267-10

Sher, A., Gazzinelli, R., Hakim, F., de la Cruz, V. F., Stover, C. K., James, S. L., et al. (1991). Immunization against parasites: bridging the gap between attenuated and non-living vaccines. Behring Inst. Mitt. 88, 244-248.

Sixsmith, J. D., Panas, M. W., Lee, S., Gillard, G. O., White, K., Lifton, M. A., et al. (2014). Recombinant Mycobacterium bovis bacillus Calmette-Guérin vectors prime for strong cellular responses to simian immunodeficiency virus gag in rhesus macaques. Clin. Vaccine Immunol. 21, 1385-1395. doi: 10.1128/CVI.00324-14

Spencer, J. C., Ganguly, R., and Waldman, R. H. (1977). Nonspecific protection of mice against influenza virus infection by local or systemic immunization with Bacille Calmette-Guerin. J. Infect. Dis. 136, 171-175. doi: 10.1093/ infdis/136.2.171

Starr, S. E., Visintine, A. M., Tomeh, M. O., and Nahmias, A. J. (1976). Effects of Immunostimulants on resistance of Newborn mice to herpes simplex type 2 infection. Proc. Soc. Exp. Biol. Med. 152, 57-60. doi: 10.3181/00379727$152-39327$

Stover, C. K., Bansal, G. P., Hanson, M. S., Burlein, J. E., Palaszynski, S. R., Young, J. F., et al. (1993). Protective immunity elicited by recombinant 
bacille Calmette-Guerin (BCG) expressing outer surface protein A (OspA) lipoprotein: a candidate Lyme disease vaccine. J. Exp. Med. 178, 197-209. doi: $10.1084 /$ jem.178.1.197

Stover, C. K., de la Cruz, V. F., Fuerst, T. R., Burlein, J. E., Benson, L. A., Bennett, L. T., et al. (1991). New use of BCG for recombinant vaccines. Nature 351, 456-460. doi: 10.1038/351456a0

Taylor, M. G., Huggins, M. C., Shi, F., Lin, J., Tian, E., Ye, P., et al. (1998). Production and testing of Schistosoma japonicum candidate vaccine antigens in the natural ovine host. Vaccine 16, 1290-1298. doi: 10.1016/S0264-410X(98) 00055-3

Tiwari, S., Casey, R., Goulding, C. W., Hingley-Wilson, S., and Jacobs, W. R. Jr. (2019). Infect and inject: how mycobacterium tuberculosis exploits its major virulence-associated type VII secretion system, ESX-1. Microbiol. Spectr. 7, 3-7. doi: 10.1128/microbiolspec.BAI-0024-2019

Van't Wout, J. W., Poell, R., and van Furth, R. (1992). The role of BCG/PPDactivated macrophages in resistance against systemic candidiasis in mice. Scand. J. Immunol. 36, 713-719. doi: 10.1111/j.1365-3083.1992. tb03132.x

Varaldo, P. B., Leite, L. C., Dias, W. O., Miyaji, E. N., Torres, F. I., Gebara, V. C., et al. (2004). Recombinant Mycobacterium bovis BCG expressing the Sm14 antigen of Schistosoma mansoni protects mice from cercarial challenge. Infect. Immun. 72, 3336-3343. doi: 10.1128/IAI.72.6.3336-3343.2004

Vierboom, M. P. M., Dijkman, K., Sombroek, C. C., Hofman, S. O., Boot, C., Vervenne, R. A. W., et al. (2021). Stronger induction of trained immunity by mucosal BCG or MTBVAC vaccination compared to standard intradermal vaccination. Cell. Rep. Med. 2:100185. doi: 10.1016/j.xcrm.2020.100185

Wei, S. H., Yin, W., An, Q. X., Lei, Y. F., Hu, X. B., Yang, J., et al. (2008). A novel hepatitis $\mathrm{C}$ virus vaccine approach using recombinant bacillus Calmette-Guerin expressing multi-epitope antigen. Arch. Virol. 153, 1021-1029. doi: 10.1007/s00705-008-0082-1

Yu, Q., Huang, X., Gong, P., Zhang, Q., Li, J., Zhang, G., et al. (2013). Protective immunity induced by a recombinant BCG vaccine encoding the cyclophilin gene of toxoplasma gondii. Vaccine 31, 6065-6071. doi: 10.1016/j.vaccine. 2013.10.015

Zhang, L., Ru, H. W., Chen, F. Z., Jin, C. Y., Sun, R. F., Fan, X. Y., et al. (2016). Variable virulence and efficacy of BCG vaccine strains in mice and correlation With genome polymorphisms. Mol. Ther. 24, 398-405. doi: $10.1038 / \mathrm{mt} .2015 .216$

Zheng, Y.-Q., Naguib, Y. W., Dong, Y., Shi, Y.-C., Bou, S., and Cui, Z. (2015). Applications of bacillus Calmette-Guerin and recombinant bacillus CalmetteGuerin in vaccine development and tumor immunotherapy. Expert Rev. Vaccines 14, 1255-1275. doi: 10.1586/14760584.2015.1068124

Zimmermann, P., Donath, S., Perrett, K. P., Messina, N. L., Ritz, N., Netea, M. G., et al. (2019). The influence of neonatal Bacille Calmette-Guérin (BCG) immunisation on heterologous vaccine responses in infants. Vaccine 37, 3735-3744. doi: 10.1016/j.vaccine.2019.03.016

Conflict of Interest: The authors declare that the research was conducted in the absence of any commercial or financial relationships that could be construed as a potential conflict of interest.

Publisher's Note: All claims expressed in this article are solely those of the authors and do not necessarily represent those of their affiliated organizations, or those of the publisher, the editors and the reviewers. Any product that may be evaluated in this article, or claim that may be made by its manufacturer, is not guaranteed or endorsed by the publisher.

Copyright (๑ 2021 Mouhoub, Domenech, Ndao and Reed. This is an open-access article distributed under the terms of the Creative Commons Attribution License (CC BY). The use, distribution or reproduction in other forums is permitted, provided the original author(s) and the copyright owner(s) are credited and that the original publication in this journal is cited, in accordance with accepted academic practice. No use, distribution or reproduction is permitted which does not comply with these terms. 